\title{
Regional Diffusion of Divorce in Turkey
}

\author{
Kim Caarls ${ }^{1}$ (D) Helga A. G. de Valk ${ }^{1}$
}

Received: 5 July 2016/Accepted: 2 August 2017/Published online: 3 October 2017

(C) The Author(s) 2017. This article is an open access publication

\begin{abstract}
While demographic change has been well documented for many Western countries, much less is known about demographic transitions in other countries, including Turkey. Demographic change in European societies can be characterized by, amongst others, increased prevalence of divorce. Although it is often argued that life courses in Turkey follow a more traditional path, little is known on determinants and patterns of divorce, despite the major socioeconomic changes Turkey has undergone over the past decades. We study the levels of divorce of women in Turkey from 1973 to 2008 to explain patterns of divorce, looking at the role of individual characteristics and the regional context. We use the Demographic Health Surveys (2003/2008), complemented with regional data on divorce, urbanization, and GDP per capita. Applying a multilevel approach, distinguishing 12 regions, we hypothesize that regions where divorce is already more prevalent, more urbanized regions, and wealthier regions in terms of GDP per capita will increase the probability of divorce. Our analyses show that levels of divorce increased over the past decades but huge regional variation remains. Sociocultural and socioeconomic factors explain this trend, and in particular urbanization and GDP per capita are key determinants for divorce.
\end{abstract}

Keywords Divorce $\cdot$ Turkey $\cdot$ Regional context $\cdot$ Multilevel $\cdot$ Event history analysis

Kim Caarls

Caarls@nidi.nl

Helga A. G. de Valk

valk@nidi.nl

1 Netherlands Interdisciplinary Demographic Institute (NIDI)/Koninklijke Nederlandse Akademie van Wetenschappen (KNAW)/University of Groningen (UG), Lange Houtstraat 19, 2511 CV The Hague, The Netherlands 


\section{Introduction}

Divorce has been the topic of extensive research during the past decades (for overview articles see e.g., Amato 2010; Amato and James 2010; Härkönen 2013; Lyngstad and Jalovaara 2010; Wagner and Wei $\beta$ 2006). Increasing levels of divorce and other demographic changes have been linked to a shift in ideas toward family life where individualistic attitudes and higher acceptance of divergent family behaviours prevail (e.g. Härkönen 2013; Lesthaeghe 1995). While these processes have been well documented in Western countries, and in particular the USA and Europe, much less is known about demographic transitions in other regions of the world, including Turkey (Adams 2004; Rashad 2000; Tabutin and Schoumaker 2005).

It is often argued that life courses in Turkey still follow a more traditional path, yet we know little about family life transitions in general and the patterns and determinants of divorce in Turkey in particular. While higher divorce rates in Europe reflect, amongst others, the changed demographic behaviour (e.g. Härkönen 2013; Lesthaeghe 1983, 2010), it is often argued that the demographic transition in Turkey is not as advanced (Rashad 2000; Yüçeşahin and Özgür 2008). However, Turkey has undergone major socioeconomic changes over the past decades and this had its impact on family life transitions (Yüçeşahin and Özgür 2008; YükselKaptanoglu and Ergöçmen 2014). Turkey has not only witnessed a notable increase in divorce rates during the past decades (e.g. Demir 2013; Härkönen 2013; Kavas and Gündüz-Hoșgör 2010; Turkish Statistical Institute (TurkStat) 2011), this growth in levels of divorce corresponds to changes in Turkish family life in many domains during the last century: people marry later and have fewer children, and gender roles are said to be less traditional (Kavas and Thornton 2013).

These changes have been attributed to modernization processes, exposure to Western values, and socioeconomic changes. In addition, and reflecting these changes, there were several legislative developments in Turkey that affected the family. Regarding divorce, the two major changes were the introduction of the 1988 no-fault divorce law and the amendments to the Turkish Civil Code in 2001, both expanding women's rights and advancing their position in the marriage (Arat 2010; Kavas and Gündüz-Hoșgör 2010; Yüksel-Kaptanoglu and Ergöçmen 2014).

Moreover, what also makes Turkey an interesting case is the huge regional variation: there are substantial differences between regions both in terms of economic development as well as in the spread of more modern values toward family life. Considering total fertility rates (TFR), for example, in some regions, these rates proximate those of European countries, while in other regions the TFR has remained high (Yüçeşahin and Özgür 2008; Yavuz 2008). While most studies on divorce concentrate on individual socioeconomic and demographic factors that predict whether a couple divorces or not (e. g. Heaton 2002; Wagner and Wei $\beta$ 2006), macro-level factors shape the context in which a couple's union formation and dissolution takes place. Particularly, the role of regional variation within one country has remained relatively understudied (but see, e.g. Kalmijn and Unnk 2007; Lester 1999; Glass and Levchak 2014).

The aim of our paper is twofold. First, we examine divorce patterns in Turkey's 12 regions over a 40-year time period, between 1967 and 2008. We study marriage 
cohort and period effects (e.g. the impact of different laws) amongst women aged 15-49 years. Second, we aim to pinpoint the mechanisms explaining the regional variation of divorce in Turkey, by investigating the importance of both macro- and micro-level predictors simultaneously. At the macro-level, both economic factors as well as the spread of modern values may influence the probability of divorce. More specifically, we investigate the role of regional variation on the probability of divorce by considering the average share of the regional gross domestic product (GDP) per capita within the total country-level GDP per capita, the level of population density, and crude divorce rates (CDR) for each of Turkey's 12 regions. Data come from the Demographic Health Survey (DHS) (2003 and 2008 waves, http://www.dhsprogram.com) enriched with regional data from TurkStat. Multilevel discrete-time event history models are used to examine to what degree individual characteristics and the regional context influence divorce behaviour.

\section{Divorce in Turkey}

In Western countries, divorce levels began rising sharply from the $1950 \mathrm{~s}$ onward (Lesthaeghe 2010). In Turkey, an increase in divorce rates occurred later (Härkönen 2013). Yet once divorce rates were rising, changes were substantial: while the CDR was only 0.27 in 1970, it increased to 1.40 in 2008 (TurkStat 2011). Parallel to this growth in levels of divorce are other changes in Turkish family life. In addition to a rising prevalence of divorce, fertility and mortality have been decreasing, bringing Turkey's reproduction close to replacement level (DHS 2009). Furthermore, age at marriage increased, gender roles became more egalitarian, and the prevalence of patriarchal extended families declined (Yüksel-Kaptanoglu and Ergöçmen 2014). In the same vein, attitudes toward divorce became more tolerant (e.g. Kavas and Thornton 2013; TurkStat 2011). Although these changes have been connected to modernization processes and exposure to Western values, local values are not necessarily abandoned and modern and traditional values are simultaneously present in Turkish society (Kavas and Gündüz-Hoșgör 2010; Kavas and Thornton 2013; Yüçeşahin and Özgür 2008).

Although Turkish society can be characterized as patriarchal with low levels of gender equality (Göksel 2013; United Nations Development Programme (UNDP) 2005), progress has been made in this area (Yüksel-Kaptanoglu and Ergöçmen 2014). Women in Turkey increasingly challenge existing gender norms. For example, while financial decision-making was traditionally an exclusively male affair and joint bank accounts were basically non-existent, Turkish women today are managing their own bank accounts to a greater extent (Kavas and Gündüz-Hoșgör 2010). Despite these changes in gender relations that took place in Turkish family life, divorced women are still stigmatized and held accountable for their broken marriage (Kavas and Gündüz-Hoșgör 2011; Özar and Yakut-Cakar 2013).

With respect to divorce, there have been several relevant changes in Turkish law. Shortly after the foundation of the Turkish Republic in 1923, the Turkish Civil Code was adopted in 1926. This code provided women with more progressive rights compared to the Sharia law that was practiced before, such as equal inheritance and 
divorce rights for men and women. Although this code provided more gender equality, it was not until the 1980s that critiques were voiced against this code, which still reflected strong patriarchal notions regarding family matters (Arat 2010). In particular, articles underpinning women's subordinate position were criticized, such as those defining the husband as head of the family and his wife as his helper and those formalizing separate ownership in marriage. These articles were especially detrimental for women during divorce, as they were consequently left without income or property.

Due to the efforts of the women's movement (amongst others), some minor reforms took place before 2001. Turkey has signed several international conventions, such as the Convention on the Elimination of All Forms of Discrimination against Women monitored by the Committee on the Elimination of Discrimination against Women (Yüksel-Kaptanoglu and Ergöçmen 2014). Most notably, the nofault divorce was introduced in 1988 [Divorce Law (No. 3444)], allowing divorce by mutual consent (Kavas and Gündüz-Hoșgör 2010).

Yet the most significant changes took place with the 2001 amendments of the Turkish Civil Code, which significantly expanded women's rights, in particular with respect to women's position in the marriage: articles that declared the husband to be the head of the household and his wife as his helper were deleted, the minimum age of marriage was raised to 18 for both men and women (it used to be 17 and 15 , respectively), there were major changes in the property regime, from one based on separate ownership to one based on the sharing of property. This implied that in the event of divorce, women could now claim a share of the property registered in their husbands name if the property was acquired during the marriage (see Arat 2010; Kavas and Gündüz-Hoșgör 2010). Furthermore, while fathers originally had the final say over child custody, the new code provided fathers and mothers with equal leverage.

These changes in legislation took place in a context of socioeconomic developments, such as industrialization, rapid urbanization, educational expansion [particularly for women, e.g. the share of women with secondary education has increased from 34\% in 1997 to 64\% in 2010 (UNDP 2013)], and increased participation of women in economic spheres. These developments had their repercussions on Turkish family life, but these developments have not been distributed equally across Turkey. Modern and traditional values are simultaneously present in Turkish society (Cindoglu et al. 2008; Kavas and Gündüz-Hoșgör 2010; Kavas and Thornton 2013), resulting in diverse family systems across regions. While family regulations changed, practices such as arranged marriages, consanguineous marriages, and religious marriages maintained, in some regions more than others (Kavas 2010; Saadat 2015).

\section{Regional Variation in Divorce}

In 2002, Turkey was included in the Nomenclature of Territorial Units for Statistics (NUTS) within the framework of the EU harmonization process, and 12 distinct regions (NUTS I) were identified. To a large extent, the sociocultural, sociodemographic and socioeconomic differences within Turkey are mirrored in these 12 
regions (DHS 2009). The regions in the Western part of Turkey, encompassing Istanbul and İzmir, are the most urbanized and industrialized. The regions in the South have several growing industrial centres, such as Adana, Mersin, and Antalya. The capital city, Ankara, lies in Central Turkey. Besides this metropolis, the regions in Central Turkey are moderately industrial. The Northern region has a fertile coastal line and a mountainous interior, mainly occupied by small-scale farmers. The Eastern regions are economically the least developed and can be characterized by a rugged landscape.

While Turkey's CDR (the number of divorces per thousand population in a given year) has been relatively low in recent years, the prevalence of divorce differs greatly between the different regions. Whereas the overall divorce rate in 2008 was 1.40, it ranged from 0.48 in Southeast Anatolia to 1.88 in the Aegean region (TurkStat 2011), which for example equals the crude divorce rates of the Netherlands [1.9 in 2009 (Eurostat 2015)]. Several macro-level studies indicated a range of contextual factors that are correlated with the cross-national variation in divorce rates, such as the role of the normative context (Amato and Keith 1991; Lesthaeghe 1995; Wagner and Wei $\beta$ 2006; Wolfinger 1999), legislative changes toward more liberal divorce legislation (Gonzaléz and Viitanen 2009; Stevenson and Wolfers 2007; Wolfinger 1999), family policies (Engelhardt et al. 2002), and female labour market participation (Diekmann and Schmidheiny 2004; Kalmijn and Unnk 2007). While these studies typically analyse between-country variation, we are interested in variation between regions. These regions can be considered a relevant context as they provide local opportunity structures (e.g. degree of urbanization, socioeconomic situation) and cultural milieus (e.g. acceptance or prevalence of divorce) that can affect individual behaviour (Hank 2002).

We expect that not only socioeconomic features of these regions play a major role in the level of diffusion of divorce (over and beyond the role of individual socioeconomic and sociodemographic characteristics), but also that different sociocultural factors influence the prevalence of divorce. For example, social norms regarding the use and acceptance of birth control vary strongly in the different regions in Turkey (Yüçeşahin and Özgür 2008). Previous studies on fertility in Turkey demonstrated that these different reproductive behaviours of women could be explained by, amongst others, diffusion processes (Yavuz 2008; Yüçeşahin and Özgür 2008). In particular, the cultural isolation of the eastern regions has prevented the diffusion of new and innovative reproductive behaviour, resulting in high fertility rates in the eastern part contrary to declining fertility trends elsewhere in Turkey (Yüçeşahin and Özgür 2008).

In a similar vein, we expect social norms regarding divorce to differ between the 12 regions. Consequently, these different norms will result in different CDR in these regions, since a higher prevalence of divorce reflects a higher cultural acceptance of divorce (Härkönen 2013). It can be expected that higher acceptance will decrease the stigmatization of divorce, making divorce more accessible for women. We therefore hypothesize that in regions where divorce has been more prevalent in the past, women's probability of divorce in later years will be higher compared to regions with lower levels of divorce, net of other regional-level and individual-level characteristics (Hypothesis 1). 
According to the diffusion theory, new behaviours typically start in metropolitan areas, where the upper and middle classes take the lead (Liefbroer and Doureleijn 2006; Nazio and Blossfeld 2002; Reed et al. 1999; Rogers 1983; Strang and Meyer 1993; Strang and Tuma 1993; Yavuz 2008). The level of urbanization varies greatly between the 12 regions, and we expect the level of divorce to vary accordingly, with a higher probability of divorce for women that live in more urbanized regions compared to women that live in intermediate or rural regions (Hypothesis 2).

There is also huge regional variation in terms of socioeconomic development. Regions in the Western part have a much larger share of the national gross domestic product (GDP) per capita than the Northern or Eastern regions (DHS 2009). Existing micro-level studies on divorce show mixed findings when it comes to the effect of economic circumstances on the probability of divorce (Aytaç and Rankin 2009; Härkönen and Dronkers 2006; Jalovaara 2003; Lyngstad and Jalovaara 2010). Several scholars studying these micro-level effects argue that acquiring a higher income has a stabilizing effect on marriages (the "income effect"). However, there is ample evidence from Europe and North America that this "income effect" will be outweighed by the so-called "independence effect", which refers to an increase in female participation on the labour market resulting in more instable marriages (Lyngstad and Jalovaara 2010). Considering the Turkish context, we expect that the "independence effect" will be minimal, as female labour market participation is extremely low (ILO 2016). Yet few studies have analysed the impact of macroeconomic circumstances on divorce (for exceptions see, e.g. Amato and Beattie 2011; Bremmer and Kesselring 2004; Schaller 2012), and even fewer looked at the effect of macroeconomic conditions on the probability of divorce on a microlevel (e.g. Fischer and Liefbroer 2006). As with micro-level studies, previous macro-level studies typically discuss two opposing hypotheses. On the one hand, it is suggested that economic hardship increases the chance of divorce, with worse economic circumstances leading to more divorce and better economic conditions resulting in less divorce. On the other hand, difficult economic conditions may make it challenging to cover the costs of divorce, making divorce less likely (Fischer and Liefbroer 2006). To account for the specific Turkish context, where the social and financial cost for divorce is high, we expect the second hypothesis to hold: bad economic conditions will lead to less divorce (Aytaç and Rankin 2009; Fischer and Liefbroer 2006; Kavas and Gündüz-Hoșgör 2010) (Hypothesis 3).

\section{Changes Over Time: Cohort and Period Effects}

Divorces in Turkey have significantly increased over the past 40 years, with CDR rising from 0.27 in 1970 to 1.40 in 2008 (TurkStat 2011). In addition to examining the role of individual and regional characteristics, we are also interested in explaining this increase in divorce over time, and to investigate whether period or cohort effects drive this change. Marriage cohort effects relate to the timing of marriage and the conditions that were present at that time. Consequently, different marriage cohorts have different attitudes, resources and practices, and these differences affect divorce rates (Härkönen 2013; Lyngstad and Jalovaara 2010). 
Period effects, in turn, affect all married couples, regardless of when they were married. The impact of new laws, for example, can bring about such period effects (González and Viitanen 2009; Yüksel-Kaptanoglu and Ergöçmen 2014).

We explored both cohort and period effects to investigate whether the change in CDR over time is the result of the emancipating effect of the no-fault divorce law in 1988 or of the amendments in Turkey's Civil Code in 2001 (period effects) or whether these changes took place due to the changing social context wherein marriages took place (cohort effects). If period effects are present, significant changes should be seen between the periods after the 1988 and 2001 reforms (Hypothesis 4a). If cohort effects explain the changes over time, we should see more gradual changes over the studied time span (Hypothesis $4 b$ ).

Previous studies also addressed the issue whether the predictors of divorce change over time (Bernardi and Martínez-Pastor 2011; De Graaf and Kalmijn 2006; Härkönen and Dronkers 2006; Härkönen 2013). In particular, previous studies have shown the effect of women's education on divorce to change over time. According to the so-called Goode hypothesis, the society presents a normative context that shapes individual divorce behaviour; when, in a given context, divorce is a relatively rare and often stigmatized event, it takes more resources to dissolve a marriage (Goode 1962). This implies that when divorce is not so common, higher educated women are more likely to break up (De Graaf and Kalmijn 2006; Härkönen and Dronkers 2006; Bernardi and Martínez-Pastor 2011). Additionally, women with higher socioeconomic status will be most likely to be the early adapters or innovators of new behaviours, such as divorce (Blossfeld et al. 1995; Hoem 1997).

For the Turkish fertility transition, higher educated women speaking Turkish were identified as the pioneers (Yavuz 2008). A higher socioeconomic status also makes women less sensitive to social conformities, even in spite of a sociocultural context in Turkey that typically represents patriarchal norms and values (Kavas and Gündüz-Hoșgör 2011). However, according to Goode's hypothesis, when divorce becomes more common, lower educated women will also experience divorce and eventually, the effect of education will be reversed, with lower educated being more likely to divorce (De Graaf and Kalmijn 2006). We therefore anticipate that women with a higher education will have a higher risk of divorce in the earlier years of our observation period, when divorce was relatively uncommon (Hypothesis 5).

Additionally, we expect that the effect of women's education on divorce will be shaped by the regional context. Similarly, we expect that in regions where divorce is a rare phenomenon, the probability of divorce is higher for women with higher education, relative to women with less education (Hypothesis 6). Additionally, in less metropolitan, rural areas, where divorce is uncommon and less accepted, the probability of divorce is higher for women with higher education compared to women with less education (Hypothesis 7). With respect to wealthier regions, we hypothesize that the relation between the economic context and the probability of divorce will be most pronounced amongst those with less education; that is, better socioeconomic circumstances stabilize marriages amongst those with less education and the divorce risk of higher educated women will increase relative to those of lower educated women (Hypothesis 8). 


\section{Micro-level Indicators of Divorce}

The main focus of our study is on regional variance in divorce and changes over time. In order to do so we, however, control for a range of micro-level characteristics. We include indicators that have proved to be strong predictors of divorce in a range of earlier studies (for review articles, see Amato 2000, 2010; Amato and James 2010; Lyngstad and Jalovaara 2010; Härkönen 2013). In line with these previous works, we control for union (like the duration of marriage, age at marriage, age heterogamy, children born in the union, children from other than spouse) and individual characteristics (like childhood place of residence, mother's literacy). In the Turkish context, there are several union-specific characteristics that also are essential to include (arranged marriages, consanguineous marriages) in addition to a distinction between the different ethnic groups in the country (indicated by mother tongue Kurdish) (Kavas 2010; Yavuz 2008). In line with the hypotheses formulated before, we are also particularly interested in the interaction between individual educational attainment (micro) and the regional diversity and cohort and period changes (macro). Educational attainment of the women is a key micro-level variable.

\section{Data and Method}

The data used in our analyses are the Turkish Demographic and Health Survey (DHS), waves 2003 and 2008. In these surveys, households were randomly sampled within the 12 regions of Turkey. In each of these households, all women that were present in the household, or who usually live in that household, have been interviewed if they were between the ages of 15 and 49 and had been ever married. For more details about the DHS surveys, their target population and response rates, please see the full DHS 2003 and DHS 2008 reports (DHS 2004: p. 183, 2009: p. 222).

Two waves of data collection have been pooled, providing us with a robust number of divorced and married Turkish women (742 and 15,480, respectively), ${ }^{1}$ covering marriages that took place between 1967 and 2008. The survey contains a wide range of demographic and health-based questions, and it includes a history of women's marriages. As the number of recorded marriages varies per wave, and the number of women with more than one marriage is limited, we will focus on first marriages only. ${ }^{2} \mathrm{We}$ consider whether these first marriages ended in divorce or not.

\footnotetext{
${ }^{1}$ Since we pool the two surveys, we de-normalized the weights using the following formula: new weight $=($ DHS sample weight $/ 1,000,000) *($ female population aged $15-49$ in survey year/sample size of survey year). Population numbers were derived from the 2000 and 2005 General Population Census (United Nations (UN) 2015). These new weights were added to the data file and used for descriptive analyses only.

${ }^{2}$ Our analytical sample of divorced women included both those who did not as well as who did remarry although the latter category was very limited: in 2003, only 3.0\% $(n=244)$ women and in 2008 only $2.5 \%(n=186)$ remarried.
} 
Using the retrospective information, we constructed a person-period file with respondents' information on a yearly basis. We followed respondents from the year of their first marriage until divorce or in case of censoring by the time of the survey or by the death of the spouse. Additionally, we excluded respondents from whom we did not have complete information concerning the start and end years of their marriage ( $n=15$ and $n=23$, respectively). This resulted in a dataset consisting of 15,418 respondents; 726 respondents experienced divorce or separation. The first divorce occurred in 1973 and the last occurred in 2008. Our definition of divorce includes women who are living together in an unmarried or a married union as the Turkish DHS survey does not distinguish between them. Although we might therefore slightly overestimate the number of married women, we expect the extent of this bias to be minimal, as non-marital cohabitation hardly occurs in Turkey (Yavuz 2008).

Since we want to explore the effects of individual and context-level factors on women's probability of divorce, we use multilevel discrete-time logistic regression models that enable us to simultaneously use explanatory variables at these two levels (i.e. individual and regional) (Snijders and Bosker 1999). The person-period file consisted of 222,616 person-years and we differentiated between 12 regions. We assessed the duration dependency by using the number of years of marriage. We tested for nonlinear effects, and the inclusion of a linear and a squared term fitted the data best. The time-varying variables were lagged with one year, which is in line with standard event history procedures (Singer and Willett 2003).

We first modelled a null model, which includes the random intercept and the variable for duration of marriage (cf. Hox 2002: p. 81). To account for the hierarchical structure of the data, all subsequent models include the random intercept. Next, we included all individual variables. In our subsequent models, we include the regional variables (due to our limited sample size at the regional level and to avoid multicollinearity, we decided to estimate our regional variables separately), and we additionally estimate models to examine period and marriage cohort effects. Finally, we investigate interaction effects to examine whether the effect of education has changed over time and whether the regional characteristics shape the effect of education.

\subsection{Measures of Contextual Variables}

We distinguished 12 geographical regions (NUTS-1) as the region in which respondents living at the time of survey. Three variables were constructed on the regional level. First, we were interested in regional CDR. This information was not available for the entire time period we were interested in. We were, however, able to obtain information about divorces per province. Today, Turkey is divided in 81 provinces (before 1989, there were 67 provinces, but several changes between 1989 and 1999 resulted in 81 provinces since then [for detailed information about Turkey's administrative divisions, see statoids.com/utr.html)]. Provincial crude divorce rates were available through marriage and divorce statistics from TurkStat [formally State Institute for Statistics (SIS)] for the period 2001-2008. For the period 1970-2000, the SIS provided only information about the total number of 
divorces per province. Using the six censuses that were carried out by the State Institute for Statistics from 1970-2000, we imputed the missing years to arrive at population estimates for each year, for each province. Crude divorce rates were then computed using the number of divorces and population estimates by province. Using these provincial crude divorce rates, we calculated the crude divorce rate for each of the 12 regions by taking the (weighted by population size) average divorce rate of the provinces in each region for each year (see Fig. 1, discussed below).

Second, using information about population density (population per $\mathrm{km}^{2}$ ) per region for the period 2001-2009 (OECD 2015) as a proxy for urbanization, we classified the 12 regions as rural (0-65), intermediate (66-99), and urban (100>). As this information was only available for a limited time period, we explored the variation over this distribution time, which appeared almost constant for all regions (see Fig. 2, discussed below). Therefore, we decided to include regional population density as a time-constant variable.

The third contextual variable is the average share of the regional GDP per capita within the total country-level GDP per capita for the period 1987-2000. Information concerning Turkish GDP on regional or provincial level was also only available from SIS for a limited period (1987-2001). Using population figures for each region, we first calculated regional GDP per capita (regional GDP/regional population) for the period 1987-2000. When examining the regional share of the total country-level GDP per capita for this time period, our analyses demonstrated little regional variation over time despite an overall increase in GDP (figures available upon request). This led us to include a time-constant variable that captures the average share of the regional GDP per capita as a percentage of the total countrylevel GDP per capita.

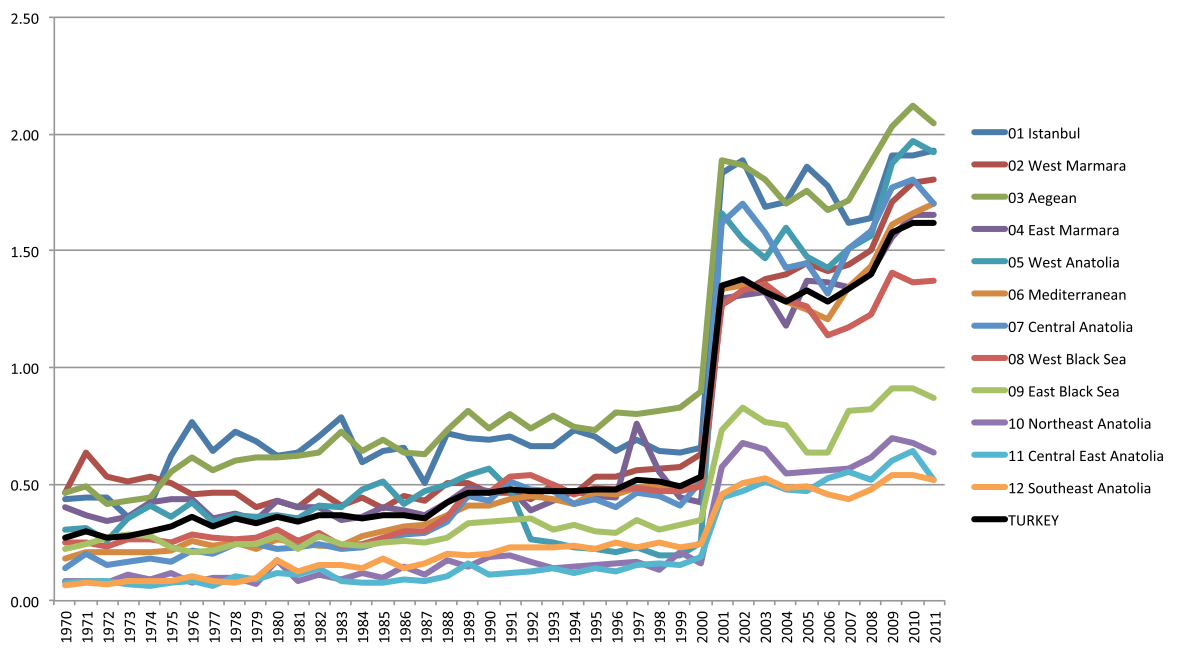

Fig. 1 Crude divorce rates by province, 1970-2011 Source: Authors' calculations (based on: Turkstat 2001-2009; SIS 1970-2000) 

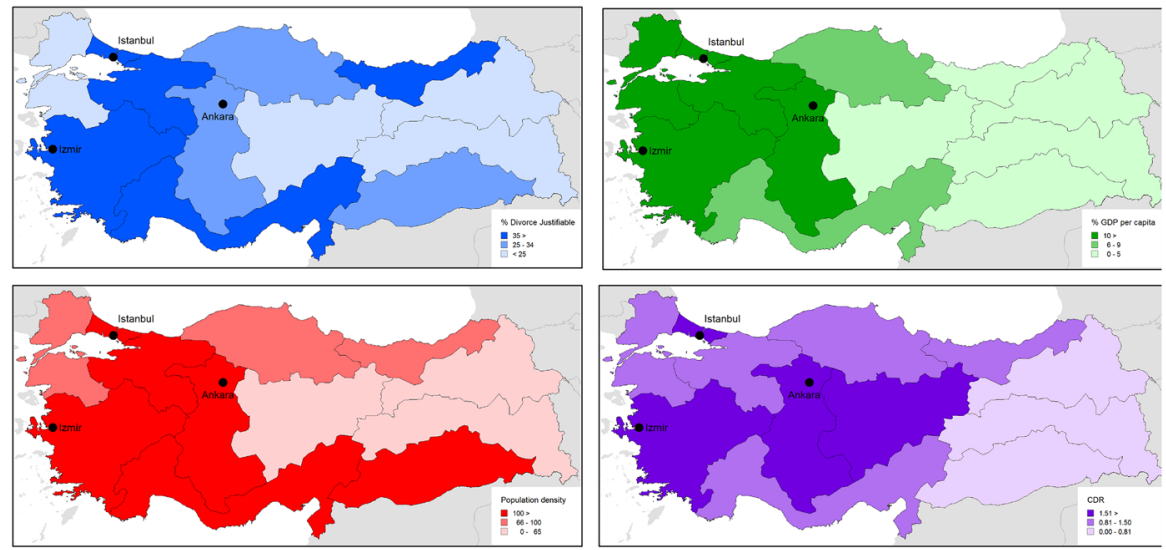

Fig. 2 Maps of Turkey showing the regional distribution of "acceptance of divorce", "share of GDP per capita", "population density", and "crude divorce rate (CDR)" (time of survey) Source: Authors' calculations [based on: TurkStat 1987-2001 (GDP per capita); WVS 2007 (Acceptance of divorce); OECD 2015 (Population density); SIS 1970-2000 and TurkStat 2001-2009 (CDR)]

\subsection{Measures of Micro-variables}

We controlled for a number of sociodemographic characteristics of the interviewed women. First, we controlled for the duration of the marriage. Women's age at marriage was treated as a continuous variable, and a squared term was added to account for nonlinear effects. The educational level at time of survey was included, referring to the highest educational level attained, distinguishing between those who have had $0=$ no, $1=$ primary, $2=$ secondary, and $3=$ tertiary education. Ideally we would have included a time-varying measure of educational attainment; unfortunately, there was no information about the educational histories of the women available. However, since most women completed their education before getting marriage, we believe the bias to be minimal.

The same holds for respondent's socioeconomic status. The DHS surveys have no variable capturing the respondent's situation before marriage. We therefore included a variable indicating whether or not the respondent's mother was literate, as a proxy of her socioeconomic status before marriage. Previous research also showed large differences in demographic behaviours between Kurdish and Turkishspeaking persons (Yavuz 2008; Yüçesahin and Özgür 2008). We thus distinguished between those with Kurdish and those with Turkish, Arabic or a different language as their native tongue. We included information about how the couples' marriage was arranged: $0=$ by the couple themselves, $1=$ by family, and $2=$ other. Additionally, since consanguineous marriages are relatively common in Turkey (Koç 2008), we controlled for this too.

Because the DHS surveys focus on women, the information about respondents' partner is much less detailed. We did have information about the husband's age at the time the union started, from which we constructed a categorical variable 
capturing the age difference between the spouses, with $0=$ wife older than husband, $1=$ same age, and $2=$ husband older than wife.

Furthermore, we took respondents' childhood residency (until age 12) into account, differentiating between respondents who $0=$ lived in a rural area, or $1=$ lived in an urban area, or $2=$ lived abroad. Finally, the DHS surveys feature a fertility module, allowing us to find out exactly at what date women have had children. As the data also give us exact information on the start and end of the marriage, we were able to consider both whether or not the couple had children (time varying, lagged with one year) and whether the respondent had children that were born from someone other than the spouse.

To be able to examine cohort and period effects, we used various measures: marriage cohort was considered by using a continuous variable "year of marriage" (centred) and a categorical variable with $0=$ before 1980, $1=1981-1990$, $2=1991-2000$, and $3=2001$ and later. Period was measured with a categorical variable, capturing the two legislative changes in 1988 and 2001, with $0=$ before $1988,1=1988-2000$, and $2=$ after 2001. Table 1 provides the descriptive statistics of all variables used in the models (in person-years).

\section{Findings}

\subsection{Regional Variation in Crude Divorce Rates and GDP per Capita}

Our analyses show clear regional variation in CDR over time (Fig. 1). For the whole of Turkey, CDR rose markedly from 0.27 in 1970 to 1.40 in 2008. Although this upward trend is more or less visible for all regions, we observe large regional differences. Figures in Southeast Anatolia range from 0.06 in 1970 to 0.48 in 2008, reflecting the lowest CDR. Today, the highest CDR can be found in the Aegean region, where CDR ranged from 0.39 in 1970 to 1.88 in 2008 . We also show how the difference in CDR between the 12 regions increased over time. While the variation in 1970 was 0.38 , this increased to 1.40 in 2008.

Two notable increases in the CDR stand out: first, an increase after 1988, and second, a large jump in CDR as of 2001. Two law reforms could be responsible for these changes: the introduction of the 1988 no-fault divorce law, which enabled divorce by mutual consent, and the 2001 amendments of the Turkish Civil Code, which further improved women's position, particularly in the event of divorce (Arat 2010; Kavas and Gündüz-Hoșgör 2010; Yüksel-Kaptanoglu and Ergöçmen 2014). The extent to which these period effects drive women's probability of divorce will be discussed later.

In Fig. 2, we show four maps of Turkey, visualizing the regional distribution of the acceptance of divorce, the average share of the regional GDP per capita within the total country-level GDP per capita, population density, and CDR at the time of survey. Even though there is variation between the twelve regions in how these four variables are distributed, these maps demonstrate the notable differences between the West and East of Turkey, whereby the West is more favourable toward divorce, richer, more urban, and with higher CDR. 
Table 1 Descriptive statistics of Turkish women aged 15-49 in person-years $(N=222,616)$

\begin{tabular}{lll}
\hline Mean (se) & $\%$ \\
\hline
\end{tabular}

Regional level (macro)

Crude divorce rate (time varying, $t-1) \quad 0.71(0.00)$

GDP per capita (regional \%)

$0.10(0.00)$

Population density

Rural

Intermediate

Urban

Individual level (micro)

Marriage duration

$10.53(0.02)$

Age at marriage

$18.90(0.01)$

Education

None

19.05

Primary

58.33

Secondary

12.25

Tertiary

10.36

Literacy mother

No

Yes

Children (time varying, $t-1$ )

No

Yes

85.12

Children from other than spouse

No

95.12

Yes

Age difference

Wife older

Same age

Husband older

84.81

Mother tongue Kurdish

No

Yes

13.89

Consanguinity

No

Yes

Arranged marriage (no $=$ ref.)

Not arranged

Family

Other

Childhood residence

$\begin{array}{lr}\text { Rural } & 54.91 \\ \text { Urban } & 43.78 \\ \text { Abroad } & 1.31\end{array}$


Table 1 continued

Source: DHS (2003, 2008) (weighted means, standard errors, and percentages)

\begin{tabular}{|c|c|c|}
\hline & Mean (se) & $\%$ \\
\hline Year of marriage (continuous) & $1986.17(0.02)$ & \\
\hline \multicolumn{3}{|l|}{ Marriage cohort } \\
\hline Before 1980 & & 29.21 \\
\hline $1981-1990$ & & 39.98 \\
\hline 1991-2000 & & 25.88 \\
\hline 2001 and later & & 4.93 \\
\hline \multicolumn{3}{|l|}{ Period: year } \\
\hline Before 1988 & & 16.82 \\
\hline $1988-2000$ & & 50.83 \\
\hline 2001 and later & & 32.35 \\
\hline
\end{tabular}

While the variation between regions changed considerably over time with respect to CDR, the average share of the regional GDP per capita within the total countrylevel GDP per capita did not change much over time. The Istanbul and East Marmara regions represent the wealthiest regions in terms of GDP per capita, with each on average $15 \%$ of the total GDP per capita. Next, the Aegean region and West Marmara are the wealthiest, encompassing on average 11\% of Turkey's GDP per capita. Northeast Anatolia, Central East Anatolia, and Southeast Anatolia are the poorest regions, representing on average 3, 4, and 5\% of the national GDP per capita, respectively.

In the same vein, the distribution of the level of population density across the 12 regions is relatively stable. Only the Mediterranean region and Southeast Anatolia changed between 2001 and 2009, both from intermediate regions to urbanized regions. In 2008, half of the regions were urban (Istanbul, Aegean, East Marmara, West Anatolia, Mediterranean, and Southeast Anatolia). Three regions were intermediate (West Marama, West Black Sea, and East Black Sea), and three regions were rural (Central Anatolia, Northeast Anatolia, Central east Anatolia).

Finally, we additionally examined regional differences concerning the attitude towards divorce, since we argued that a higher prevalence of divorce reflects a higher cultural acceptance of divorce (Härkönen 2013). The acceptance towards divorce varies across the regions, ranging from very high acceptance in some regions (e.g. 53\% in the Aegean region) to very low acceptance in other regions (e. g. $18 \%$ in West Marmara) (World Values Survey (WVS) 2007). ${ }^{3}$ Regional information concerning these attitudes was only available for 2007. Since we expect these attitudes to significantly vary over time (similar to regional CDR), we did not include this information in our multivariate analyses.

\footnotetext{
3 The original variable in the WVS (2007, V205) was coded $0=$ never justifiable to $10=$ always justifiable. We recoded this variable to a dichotomous variable with $0=$ never justifiable $(0-4)$ and $1=$ justifiable $(5>)$.
} 


\subsection{Individual and Regional Determinants of Divorce in Turkey}

We first fitted a null model, which includes the random intercept and the variable for duration of marriage (cf. Hox 2002: p. 81). Next, we include our micro-level control variables in Model 1, and in Models 2 we include our different macro-level variables. Due to the relatively small number of regions, we estimate separate models for each of our regional variables (Table 2 Models 2a, 2b, and 2c).

In Model 0 , the random intercept exhibits significant variation, demonstrated by a likelihood ratio test comparing a multilevel model to an ordinary logistic regression $(p=.000)$, and by the standard deviation of random intercepts (.305) being more than twice its standard error (.078). Although the intraclass correlation is not straightforwardly obtained in binomial models, we calculated the intraclass correlation in line with Snijders and Bosker (1999: p. 224). The intraclass correlation is 0.028 , indicating a small but significant degree of dependence between the two levels. The between-region variance, i.e. the proportion of the total variance due to the variance between regions, which is $3 \%$ in the null model, is reduced to $1 \%$ in Model 1, after including the micro-level variables. This demonstrates that the between-region variance is largely related to the population composition in these regions, in as far as we accounted for that by our micro-level variables. The random intercept still reveals significant variation at the regional level. In Models 2, the between-region variation is further reduced to less than $1 \%$ Models $2(0.3,0.3$, and $0.2 \%$, respectively) and remains only significant in Model $2 \mathrm{~b}$. This indicates that the remaining variation between regions is mostly accounted for by the various regional characteristics.

Before coming to the core of our analyses, we briefly discuss the micro-level control variables introduced in Model 1 . These variables are almost all significantly influencing the probability of divorce, in line with previous studies on the determinants of divorce. The exceptions are mother's literacy and marriage duration, which were no longer significant after controlling for the other individual characteristics. The nonlinear effect of the age at marriage shows that marrying either very young or at late age increases the risk of divorce (see Lehrer (2008) for a similar finding in the USA). The effect of education on divorce is positive and significant in all models, conforming several previous studies (e.g. Blossfeld et al. 1995; Frank and Wildsmith 2005; Hall and Zhao 1995; Kalmijn et al. 2004). This means that higher educated Turkish women are more likely to divorce than their lower educated counterparts, net of the other individual characteristics we controlled for. Having children decreases the risk of divorce, except when these children are born from someone other than the spouse, in which case women have higher risks of divorce (Härkönen and Dronkers 2006).

Marriages where the husband is older are the most stable compared to marriages where the partners have the same age or when the wife is older than her husband (Gentleman and Park 1994; Janssen et al. 1999; Kalmijn and Poortman 2006). Marriages that are reflective of more patriarchal Turkish norms are less likely to dissolve, such as arranged (Jones 2007), consanguineous (Saadat 2015), and Kurdish marriages (Yavuz 2008). Finally, women that grew up in an urban setting or who have experienced living abroad are more likely to divorce compared to 


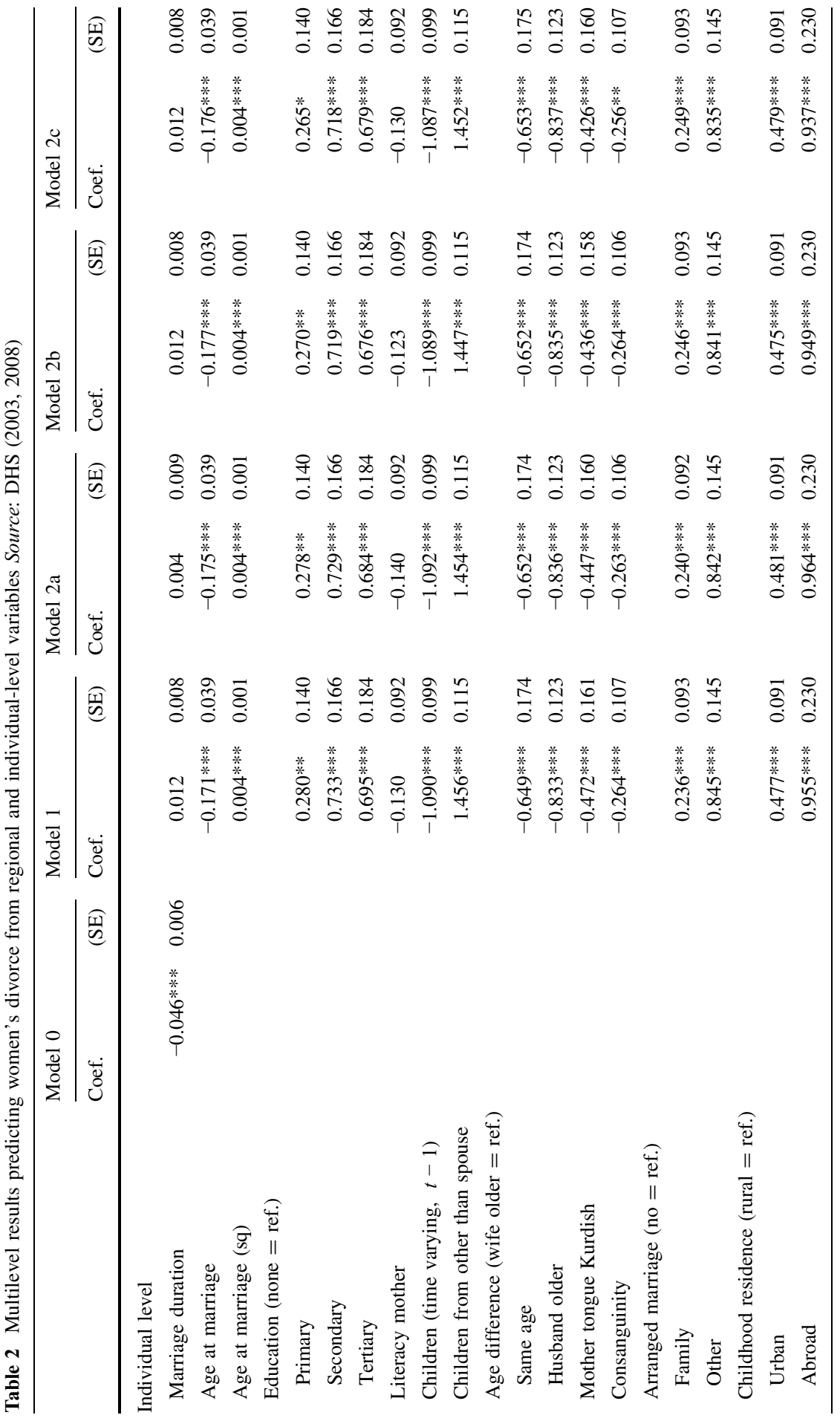




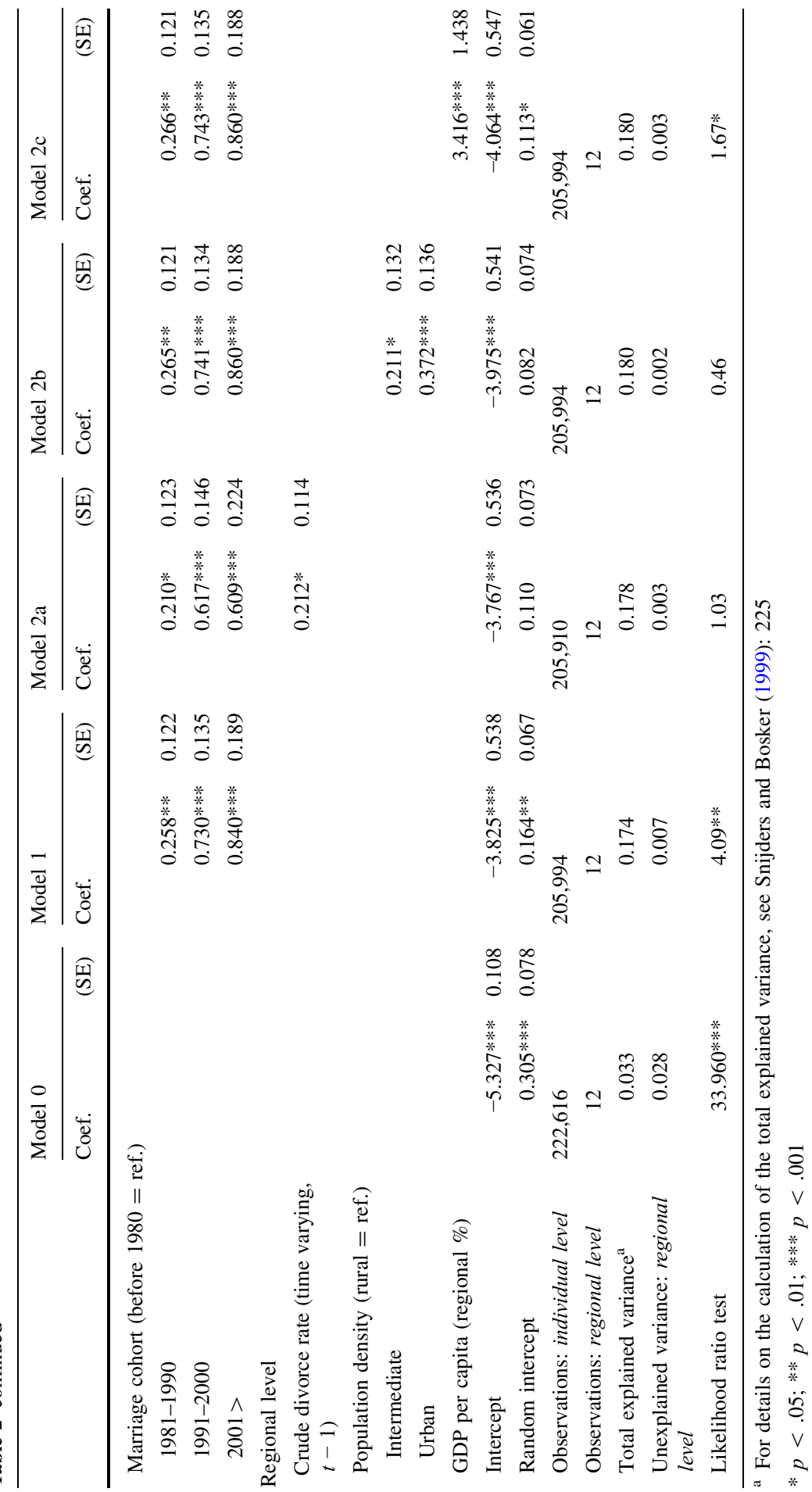


women who grew up in rural Turkey. Finally, controlling for marriage cohort, our findings illustrate that the more the recent marriage is, the more likely a divorce. These individual-level variables together explain about $17 \%$ of the total variation (see Snijders and Bosker 1999: p. 225 for the calculation of the explained variance in binomial multilevel models).

The effects of our control variables remain the same after including the regionallevel explanatory variables: the time-varying indicator capturing the regional divorce rate (lagged 1 year) (Model 2a), the time-constant variable indicating the level of population density (Model 2b), and the time-constant variable referring to the average share of the regional GDP per capita within the total country-level GDP per capita (Model 2c). As expected, women's probability of divorce is higher in regions where divorce has been more prevalent in the previous year (Hypothesis 1), and in regions that are more urbanized (Hypothesis 2). These two hypotheses might provide tentative evidence for theories on the diffusion of innovations. Considering divorce as a "new behaviour", we expected to find a higher risk of divorce in metropolitan areas (Nazio and Blossfeld 2002; Liefbroer and Doureleijn 2006; Rogers 1983; Strang and Meyer 1993; Strang and Tuma 1993; Yavuz 2008), and our analyses for Turkey confirm this. While previous evidence regarding the role of socioeconomic circumstances is mixed, we find that in wealthier and more developed regions, in terms of GDP per capita, the probability of divorce is higher (Hypothesis 3) (Aytaç and Rankin 2009; Fischer and Liefbroer 2006; Jalovaara 2003; Kavas and Gündüz-Hoșgör 2010; Lyngstad and Jalovaara 2010).

\subsection{Period and Cohort Effects on Divorce in Turkey}

In Table 3, the results of our analyses on whether period or cohort effects shape women's probability of divorce in Turkey are presented. Our previous models (Table 2), showed a strong positive effect of marriage cohort, indicating that those marrying later are more likely to divorce. In Models 1a-c (Table 3), we show again the effects of marriage cohort. In line with Fig. 1, which clearly demonstrated how the two liberating legislative changes in 1988, and most notably in 2001, shape the national and regional CDR in Turkey, we show the effect of period by including a set of dummy variables measuring the period before 1987, 1988-2000, and 2001 onwards (Models 2a-c). As the coefficients of our micro-level variables have not changed compared to the Models in Table 2, we show only the cohort, period, and regional variables here.

Looking at the total variation explained, we see that the models including marriage cohort effects are slightly better in explaining women's probability of divorce compared to the models with period effect. The models that include the categorical variable of marriage cohort have the highest variation explained, approximately 18\% (Models 2a-c, Table 2). The risk of divorce for women married between 1991-2000 or 2001 and later is approximately two times higher than women married before 1980. Similarly, the risk of divorce in the period after 2001 is also two times higher for women compared to the risk of divorce in the period before 1988. This means that we find evidence of both period and cohort effects (Hypotheses $4 a$ and 4b). 


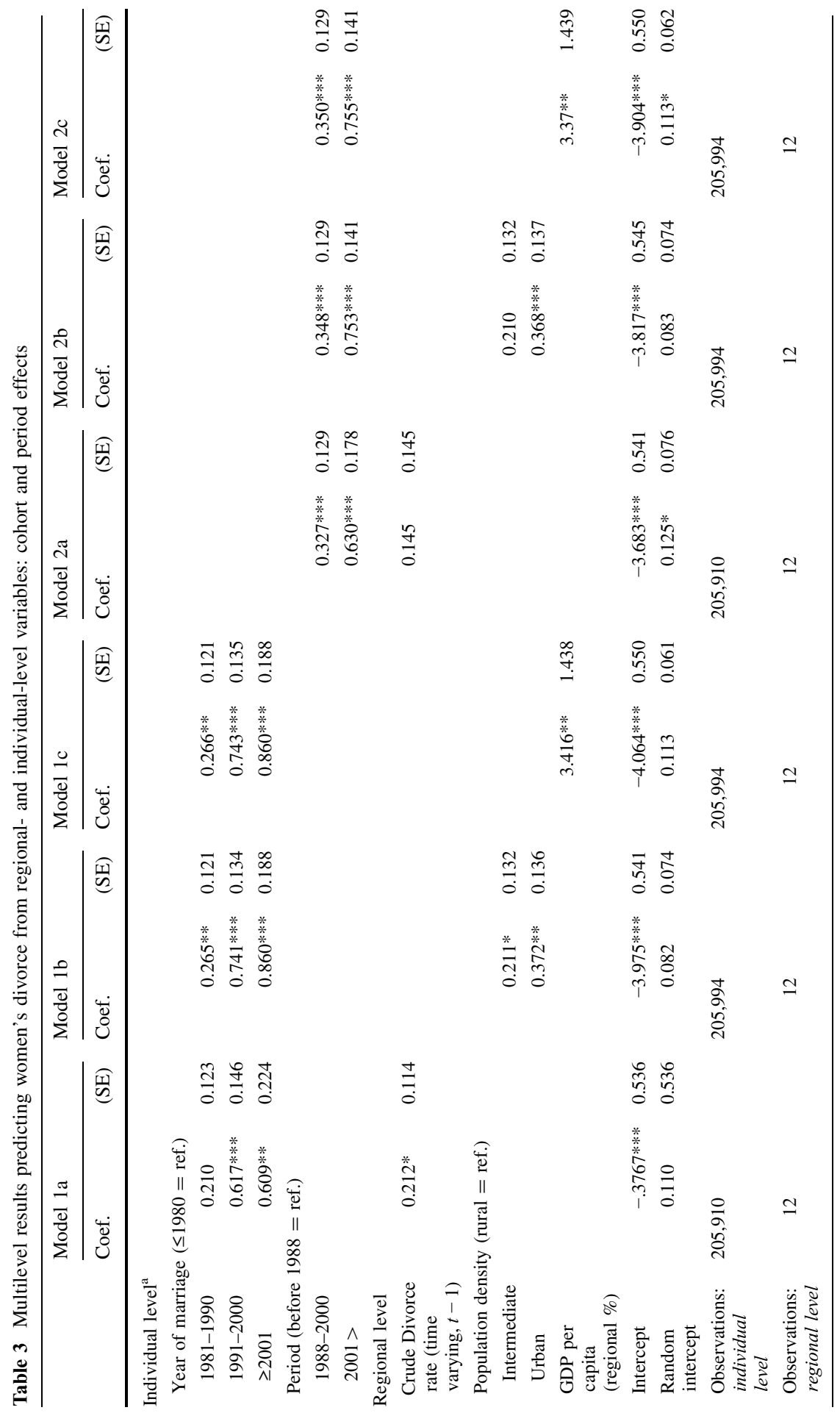




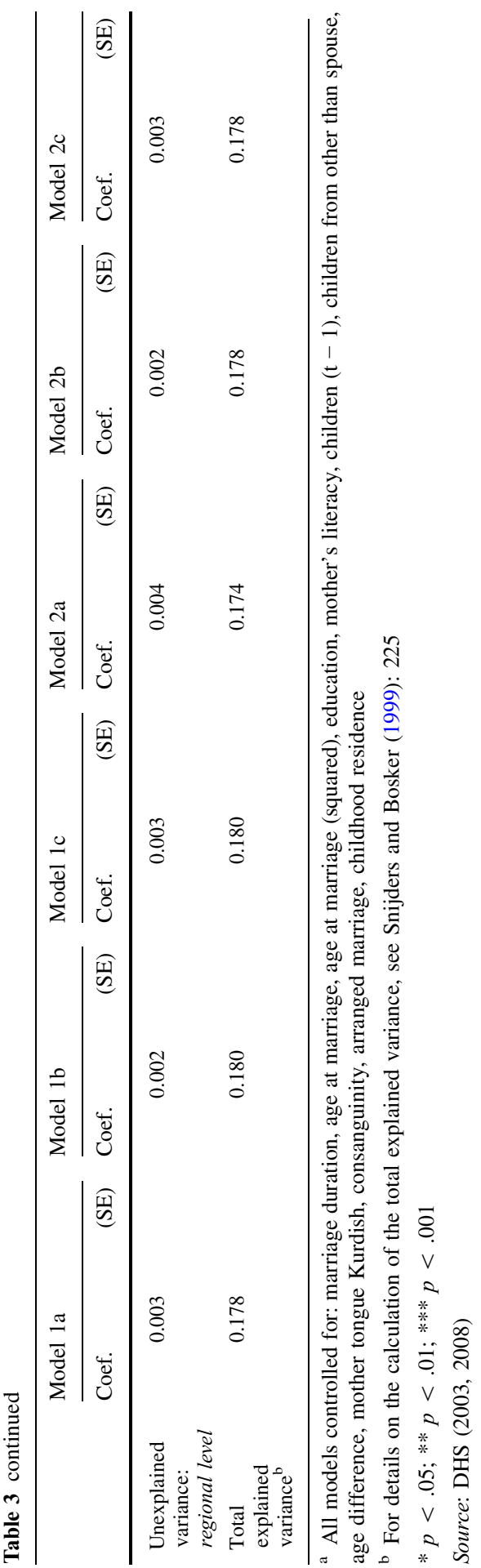




\subsection{Individual- and Cross-Level Interactions}

Table 4 shows the findings for the individual-level interactions to investigate whether the effect of education has changed over time. We do so by, using the continuous measure "year of marriage" (Models 1a-c), and cross-level interactions with the macro-variables (CDR, population density, and the average share of GDP per capita for each region) to see if they have a significant effect on the effect of education on divorce (Models 2a-c).

Contrary to the Goode (1962) hypothesis, our findings show that the effect of education does not change over time for women with higher education, relative to women with no or primary education (Models 1). This means that Hypothesis 5 is not confirmed. We find that the interaction term for primary education and regional CDR (Model 2a) is negative and significant. This means that the positive effect of education decreases for women with primary education in regions where divorce is more prevalent. We, however, do not find a significant effect for women with secondary or tertiary education, which implies that the effect of education decreases in regions where divorce is already more prevalent. The latter partly confirms our expectation (Hypothesis 6).

In Model $2 \mathrm{~b}$, we show that the probability of divorce for women with secondary education is lower in more densely populated regions. Similarly, in Model $2 \mathrm{c}$ we show that the risk of divorce for women with secondary education is lower in regions with higher average shares of GDP per capita. Both these findings correspond to our hypotheses (Hypothesis 7 and 8). It is likely that the costs of divorce are lower in more urbanized and wealthier regions, resulting in lower divorce risks for women with higher (secondary) education relative to the divorce risks of women with less (no) education (De Graaf and Kalmijn 2006; Goode 1962).

\section{Discussion}

In this article, we examined regional patterns of divorce as well as the factors contributing to women's probability of divorce in Turkey. Both the relationships between regional-level (macro) and individual-level (micro) characteristics were scrutinized. Our work adds to the existing literature on the risk of divorce in two important ways. First, the majority of studies that explain divorce risks focus on divorce within Western countries (mainly Europe and North America). NonWestern countries have received little attention thus far, even though demographic changes may alter family life substantially there too. Turkey is a particularly relevant case to study as it has witnessed major changes in family life events in recent years. Second, most studies have focused on individual characteristics in the study of divorce patterns. We add the societal regional context to our study for the case of Turkey where there is great regional variation in divorce risks. Our analyses point to three important findings.

First, since the rise of divorce in Turkey is relatively recent, divorce can be considered a "new family demographic behaviour" in the Turkish context. Theories on the diffusion of innovations postulate that new behaviours first emerge in large 


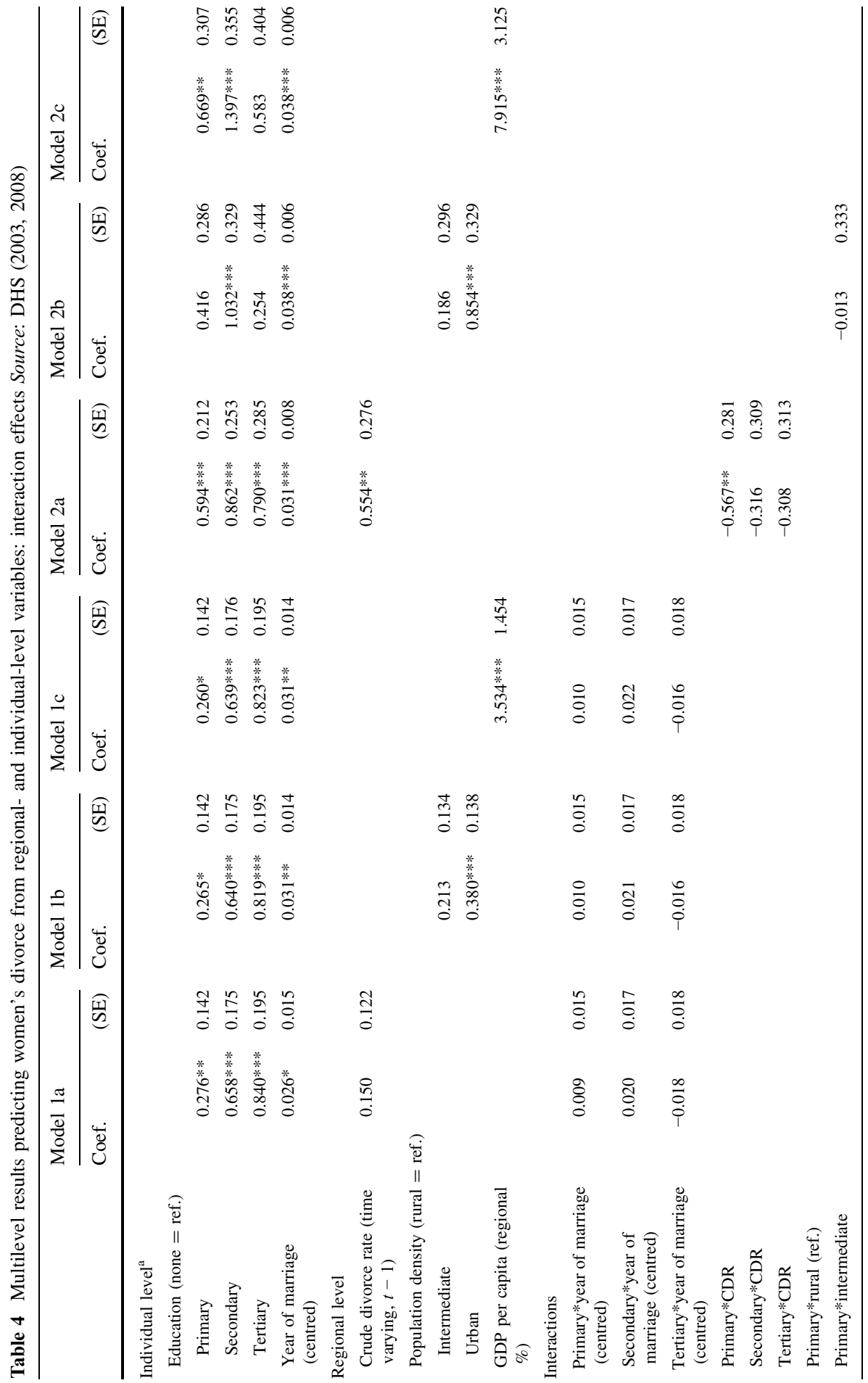




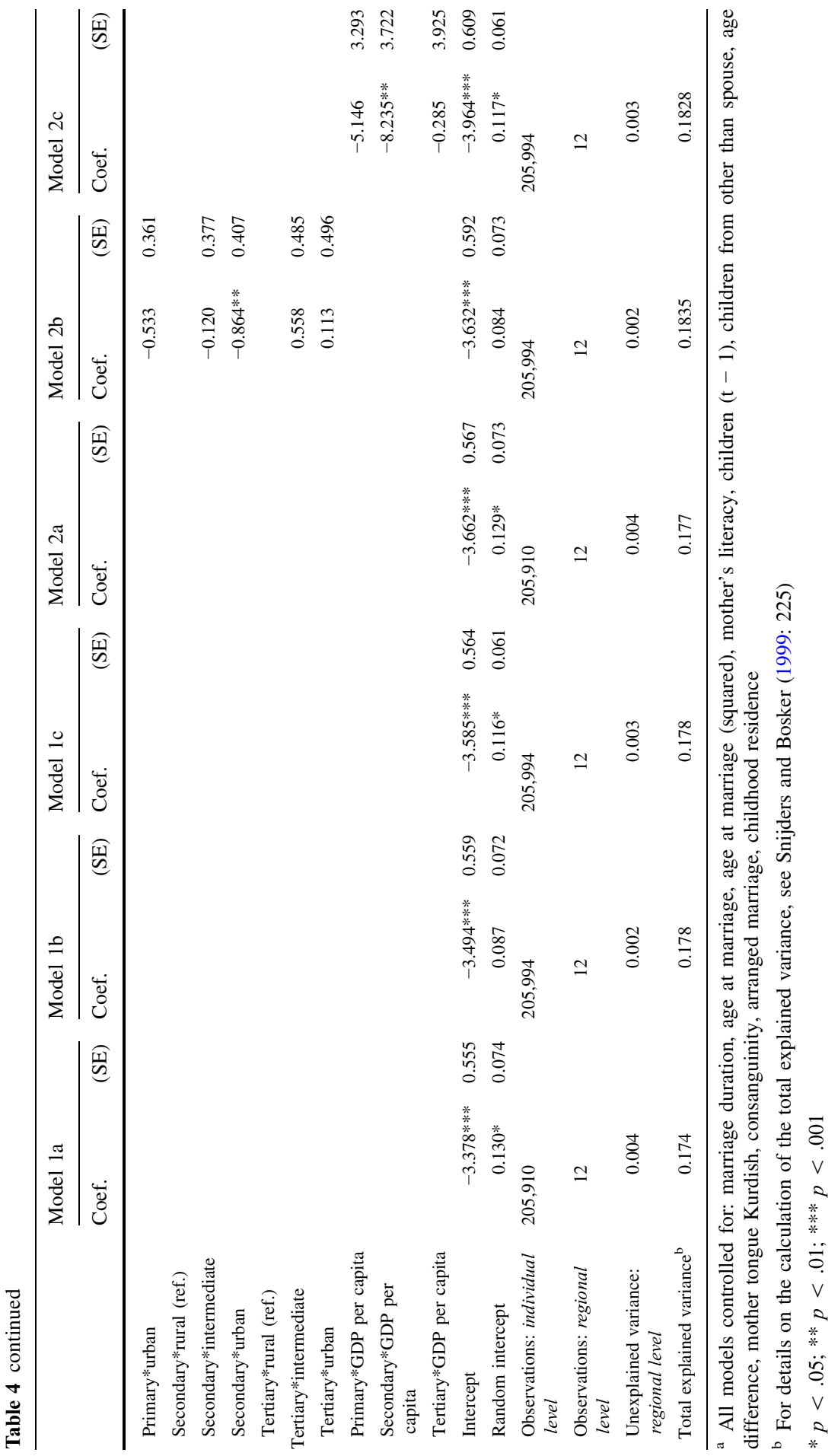


towns and cities amongst those with a higher socioeconomic status (Liefbroer and Doureleijn 2006; Nazio and Blossfeld 2002). Since we were interested in how the wider societal context of women affected their probability of divorce, we considered characteristics of the region they lived in. This regional context is particularly relevant for Turkey, given the huge variation in demographic behaviour and economic development between the 12 different regions. In line with our expectations, living in regions where the CDR is higher (Hypothesis 1), living in more urban regions (Hypothesis 2), and living in regions where the average shares of GDP per capita are higher (Hypothesis 3) increase the divorce risks of women. The fact that our study clearly shows the expected patterns for the influence of the context points to the relevance of including measures of societal environment in the study of demographic behaviour. Importantly, in addition to these regional measures, our findings also show that controlling for the composition of the population within these regions explains a large share of the between-region variation. The fact that these rather broad measures for the wider context already show such clear impact, indicates that social networks need to be studied in more detail to pinpoint the underlying mechanisms that lead to specific choices in the family life. This is relevant both in the case of Turkey as well as for societies in Europe and elsewhere.

We also found that both period and cohort effects drive women's probability of divorce. Women married in more recent years are more likely to divorce, and the two time periods corresponding to two emancipating legislative changes also demonstrate an increased risk of divorce (Hypotheses $4 a$ and $4 b$ ). Additionally, we found that higher educated women have higher probabilities to divorce, as well as women that lived in urban regions or abroad during their childhood. While the information on the exact whereabouts of these women that were internationally mobile is limited, we could speculate that they are exposed to Western contexts where divorce was already more prevalent. This in turn increases their likelihood of divorce. Our data did not allow a more fine-grained analyses but future research should link exposure to different norms and value systems in order to better determine the effect of these experiences across the life course on individual life choices.

Second, we tested whether the relationship between women's education and her probability to divorce will be more negative over time as divorce becomes more accepted (Hypothesis 5) (cf. Goode 1962). Our findings are to some extent supportive of this hypothesis, since the effect of education decreases over time. Nonetheless, women with a higher education remain more likely to divorce than their lesser-educated counterparts. This could be the result of the fact that the prevalence of divorce in Turkey is still relatively low, so that the costs of divorce remain relatively high, and those with a higher education remain the pioneers. We could speculate that when this trend of increasing divorce rates in Turkey continues, the effect of education will decrease or even become negative.

Third, we expected that the effect of women's education on divorce would also be shaped by the regional context. In line with our expectations, the effect of women's education becomes less positive in regions where divorce is more prevalent, more urban regions, and wealthier regions (Hypothesis 6, 7, and 8). These 
findings could be explained by the fact that the costs of divorce decrease in regions with higher CDR, that are more urbanized and wealthier. As a result, the divorce risk of women with higher (mostly secondary) education decreases compared to the risk of divorce of women without education (De Graaf and Kalmijn 2006; Goode 1962).

This study suggests that for Turkey, modernization and the diffusion of new family norms are associated with in an increase of divorce. However, the crosssectional nature of the DHS data limits the possibilities of studying in detail the time-varying effects of several relevant characteristics, such as education and employment. Future studies could carry this work further by studying sociodemographic processes in Turkey from a more pronounced life course perspective. Additionally, information about characteristics of the husband is limited in our data, and we were not able to distinguish between divorce and separation, whereby people live separated but have not officially divorced. This potentially underestimates our estimates of the probability of divorce in Turkey. Finally, collecting context variables over time for the 12 regions proved to be challenging. Future research could carry analyses on the role of divorce further by enriching the data with more detailed time-varying regional characteristics (for example, the labour market participation of women).

Notwithstanding these limitations, this study is amongst the few to consider the role of the regional context in shaping women's divorce risk over time. Specifically, using multilevel discrete-time models, we were able to simultaneously estimate the effects of women's individual characteristics as well as the regional characteristics on the probability of divorce over an extended period of time. This revealed the importance of period and cohort effects and the relevance of accounting for both individual and regional levels in order to better understand divorce patterns.

Acknowledgements We thank Jelle Kooistra for his help in preparing preliminary drafts of this paper during his internship at the Netherlands Interdisciplinary Demographic Institute (NIDI). This study is part of and supported by the European Research Council Starting Grant project, 'Families of migrant origin: a life course perspective' (project number 263829), awarded to Helga A. G. de Valk.

Open Access This article is distributed under the terms of the Creative Commons Attribution 4.0 International License (http://creativecommons.org/licenses/by/4.0/), which permits unrestricted use, distribution, and reproduction in any medium, provided you give appropriate credit to the original author(s) and the source, provide a link to the Creative Commons license, and indicate if changes were made.

\section{References}

Adams, B. N. (2004). Families and family study in international perspective. Journal of Marriage and Family, 66(5), 1076-1088.

Amato, P., \& Beattie, B. (2011). Does the unemployment rate affect the divorce rate: An analysis of state data 1960-2005. Social Science Research, 40(3), 704-715.

Amato, P. R. (2010). Research on divorce: Continuing trends and new developments. Journal of Marriage and Family, 72(3), 650-666.

Amato, P. R., \& James, S. (2010). Divorce in Europe and the United States: Similarities and differences across nations. Family Science: Journal of the European Society on Family Relations, 1, 2-13. 
Amato, P. R., \& Keith, B. (1991). Parental divorce and adult well-being: A meta analysis. Journal of Marriage and Family, 53(1), 43-58.

Arat, Y. (2010). Women's rights and Islam in Turkish politics: The civil code amendment. Middle East Journal, 64(2), 235-251.

Aytaç, I. A., \& Rankin, B. H. (2009). Economic crisis and marital problems in Turkey: Testing the family stress model. Journal of Marriage and Family, 71(3), 756-767.

Bernardi, F., \& Martínez-Pastor, J.-I. (2011). Divorce risk factors and their variations over time in Spain. Demographic Research, 24(31), 771-800.

Blossfeld, H. P., De Rose, A., Hoem, J. P., \& Rohwer, G. (1995). Education, modernization, and the risk of marriage disruption in Sweden, West Germany, and Italy. In K. Mason \& A. Jensen (Eds.), Gender and family change in industrialized countries (pp. 200-222). Oxford: Clarendon Press.

Bremmer, D., \& Kesselring, R. (2004). Divorce and female labor force participation: Evidence from timeseries data and cointegration. Atlantic Economic Journal, 32(3), 175-190.

Cindoglu, D., Cemrek, M., Toktas, S., \& Zencirci, G. (2008). The family in Turkey: The battleground of the modern and the traditional. In C. B. Hennon \& S. M. Wilson (Eds.), Families in a global context (pp. 235-263). London: Routledge.

De Graaf, P., \& Kalmijn, M. (2006). Change and stability in the social determinants of divorce: A comparison of marriage cohorts in the Netherlands. European Sociological Review, 22(5), 561-572.

Demir, S. A. (2013). Attitudes toward concepts of marriage and divorce in Turkey. American International Journal of Contemporary Research, 3(12), 83-88.

Demographic Health Survey (DHS). (2004). Turkey Demographic Health Survey, 2003. Hacettepe University Institute of Population Studies, Ministry of Health General Directorate of Mother and Child Health and Family Planning, State Planning Organization. Ankara, Turkey.

Demographic Health Survey (DHS). (2009). Turkey Demographic Health Survey, 2008. Ankara, Turkey: Hacettepe University Institute of Population Studies, Ministry of Health General Directorate of Mother and Child Health and Family Planning, State Planning Organization.

Diekmann, A., \& Schmidheiny, K. (2004). Do parents of girls have a higher risk of divorce? An eighteen country study. Journal of Marriage and Family, 66(3), 651-660.

Engelhardt, H., Trappe, H., \& Dronkers, J. (2002). Differences in family policy and the intergenerational transmission of divorce. A comparison between the former East and West Germanies. Demographic Research, 6(11), 296-324.

Eurostat. (2015). Marriage and divorce statistics. Retrieved from http://ec.europa.eu/eurostat/statisticsexplained/index.php/Marriage_and_divorce_statistics.

Fischer, T., \& Liefbroer, A. C. (2006). For richer, for poorer: The impact of macroeconomic conditions on union dissolution rates in the Netherlands 1972-1996. European Sociological Review, 22(5), 519532 .

Frank, R., \& Wildsmith, E. (2005). The grass widows of Mexico: Migration and union dissolution in a binational context. Social Forces, 83(3), 919-947.

Gentleman, J. F., \& Park, E. (1994). Age differences of married and divorcing couples. Health Reports, 6 (2), 225-239.

Glass, J., \& Levchak, P. (2014). Red states, blue states, and divorce-Understanding the impact of conservative Protestantism on regional variation in divorce rates. American Journal of Sociology, 119, $1-44$.

Göksel, I. (2013). Female labor force participation in Turkey: The role of conservatism. Women's Studies International Forum, 41(1), 45-54.

Gonzaléz, L., \& Viitanen, T. K. (2009). The effect of divorce laws on divorce rates in Europe. European Economic Review, 53(2), 127-138. doi:10.1016/j.euroecorev.2008.05.005.

Goode, W. J. (1962). Marital satisfaction and instability: A cross-cultural class analysis of divorce rates. International Social Science Journal, 14, 507-526.

Hall, D. R., \& Zhao, J. Z. (1995). Cohabitation and divorce in Canada: Testing the selectivity hypothesis. Journal of Marriage and Family, 57, 421-427.

Hank, K. (2002). Regional social contexts and individual fertility decisions: A multilevel analysis of first and second births in Western Germany. European Journal of Population, 18, 281-299.

Härkönen, J. (2013). Divorce: Trends, patterns, causes, consequences (Working paper 2013:3). Stockholm: Stockholm University Linnaeus Center on Social Policy and Family Dynamics in Europe, SPaDE.

Härkönen, J., \& Dronkers, J. (2006). Stability and change in the educational gradient of divorce. A comparison of seventeen countries. European Sociological Review, 22(5), 501-517. 
Heaton, T. B. (2002). Factors contributing to increasing stability in the United States. Journal of Family Issues, 23(3), 392-409.

Hoem, J. M. (1997). Educational gradients in divorce risks in Sweden in recent decades. Population Studies, 51, 19-28.

Hox, J. (2002). Multilevel analysis: Techniques and applications. Mahwah, NJ: Lawrence Erlbaum Associates.

ILO. (2016). Female labor force participation rates. Retrieved from https://www.ilo.org/ilostat.

Jalovaara, M. (2003). The joint effects of marriage partners' socioeconomic positions on the risk of divorce. Demography, 40, 67-81.

Janssen, J. P. G., De Graaf, P. M., \& Kalmijn, M. (1999). Heterogamie en echtscheiding: Een analyse van Nederlandse registergegevens 1974-1994. Bevolking en Gezin, 28, 35-57.

Jones, G. W. (2007). Modernization and divorce: Contrasting trends in Islamic Southeast Asia and the West. Population and Development Review, 23(1), 95-114.

Kalmijn, M., De Graaf, P. M., \& Poortman, A.-R. (2004). Interactions between cultural and economic determinants of divorce in the Netherlands. Journal of Marriage and Family, 66(1), 75-89.

Kalmijn, M., \& Poortman, A.-R. (2006). His or her divorce? The gendered nature of divorce and its determinants. European Sociological Review, 22(2), 201-214.

Kalmijn, M., \& Unnk, W. (2007). Regional value differences in Europe and the social consequences of divorce: A test of the stigmatization hypothesis. Social Science Research, 36, 447-468.

Kavas, S. (2010). Post- divorce experience of highly educated and professional women. Unpublished doctoral dissertation, Middle East Technical University Turkey.

Kavas, S., \& Gündüz-Hoșgör, A. (2010). Divorce and family change revisited: Professional women's divorce experience in Turkey. Demográfia, 53(5), 102-126.

Kavas, S., \& Gündüz-Hoșgör, A. (2011). "It is not a big deal, I can do it, too": Influence of parental divorce on professional women's marital experience in Turkey. Journal of Divorce \& Remarriage, 52(8), 565-585.

Kavas, S., \& Thornton, A. (2013). Adjustment and hybridity in Turkish family change: Perspectives from developmental idealism. Journal of Family History, 38(2), 223-241.

Koç, I. (2008). Prevalence and sociodemographic correlates of consanguineous marriages in Turkey. Journal of Biosocial Science, 40(1), 137-148.

Lehrer, E. (2008). Age at marriage and marital instability: Revisiting the Becker Landes-Michael hypothesis. Journal of Population Economics, 21, 463-484.

Lester, D. (1999). Regional differences in divorce rates. Journal of Divorce \& Remarriage, 30, 121-124.

Lesthaeghe, R. (1983). A century of demographic and cultural change in Western Europe: An exploration of underlying dimensions. Population and Development Review, 9(3), 411-435.

Lesthaeghe, R. (1995). The second demographic transition in Western countries: An interpretation (Working paper No. 1991-2). Brussel: Vrije Universiteit Brussel, Interuniversity Programme in Demography.

Lesthaeghe, R. (2010). The unfolding story of the second demographic transition. Population and Development Review, 36(2), 211-251.

Liefbroer, A. C., \& Doureleijn, E. (2006). Unmarried cohabitation and union stability: Testing the role of diffusion using data from 16 European countries. Demography, 43(2), 203-221.

Lyngstad, T. H., \& Jalovaara, M. (2010). A review of the antecedents of union dissolution. Demographic Research, 23, 255-292.

Nazio, T., \& Blossfeld, H.-P. (2002). The diffusion of cohabitation among young women in West Germany, East Germany and Italy. European Journal of Population, 19(1), 47-82.

Organisation for Economic Co-operation and Development (OECD). (2015). OECD.Stat: Regional demography [New Regional Database, released July 2015]. http://stats.oecd.org/viewhtml.aspx? datasetcode=REGION_DEMOGR\&lang=en\#.

Özar, S., \& Yakut-Cakar, B. (2013). Unfolding the invisibility of women without men in the case of Turkey. Women's Studies International Forum, 41(1), 24-34.

Rashad, H. (2000). Demographic transition in Arab countries: A new perspective. Journal of Population Research, 17(1), 83-101.

Reed, H., Briere, R., \& Casterline, J. (1999). The role of diffusion process in fertility change in developing countries. Washington DC: National Academy Press.

Rogers, E. M. (1983). Diffusion of innovations (3rd ed.). New York: Free Press.

Saadat, M. (2015). Association between consanguinity and survival of marriages. Egyptian Journal of Medical Human Genetics, 16(1), 67-70. 
Schaller, J. (2012). For richer, if not for poorer? Marriage and divorce over the business cycle. Journal of Population Economics, 26, 1007-1033.

Singer, J., \& Willett, J. (2003). Applied longitudinal data analysis: modeling change and event occurrence. New York: Oxford University Press.

Snijders, T. A. B., \& Bosker, R. J. (1999). Multilevel analysis: An introduction to basic and advanced multilevel modeling. London: Sage Publications.

Stevenson, B., \& Wolfers, J. (2007). Marriage and divorce: Changes and their driving forces. Journal of Economic Perspectives, 21(2), 27-52.

Strang, D., \& Meyer, J. W. (1993). Institutional conditions for diffusion. Theory and Society, 22, 487-511.

Strang, D., \& Tuma, N. B. (1993). Spatial and temporal heterogeneity in diffusion. American Journal of Sociology, 99, 614-639.

Tabutin, D., \& Schoumaker, B. (2005). The demography of the Arab World and the Middle East from the 1950 s to the 2000s. Populations-E, 60(4), 505-616.

Turkish Statistical Institute (TurkStat). (2011). Marriage and divorce statistics 2011. General Directorate of Civil Registration and Nationality and Turkish Statistical Institute. Ankara: Turkish Statistical Institute Printing Division.

United Nations (UN). (2015). World population prospects: The 2015 revision. Department of Economic and Social Affairs, Population Division.

United Nations Development Programme (UNDP). (2005). United nations development programme Turkey. Ankara: UNDP.

United Nations Development Programme (UNDP). (2013). International human development indicators. http://hdrstats.undp.org/en/indicators/default.html.

Wagner, M., \& Wei $\beta$, B. (2006). On the variation of divorce risks in Europe: Findings from a metaanalysis of European longitudinal studies. European Sociological Review, 22(5), 483-500.

Wolfinger, N. H. (1999). Trends in the intergenerational transmission of divorce. Demography, 36, 415420.

World Values Survey (WVS). (2007). World values survey wave 5 2005-2008 official aggregate v.20140429: Turkey 2007. World Values Survey Association (www.worldvaluessurvey.org). Aggregate File Producer: Asep/JDS, Madrid, Spain.

Yavuz, S. (2008). Fertility decline in Turkey from the 1980s onwards: Patterns by main language groups. Unpublished doctoral dissertation, Hacettepe University Turkey.

Yüçeşahin, M. M., \& Özgür, E. M. (2008). Regional fertility differences in Turkey: Persistent high fertility in the Southeast. Population, Space and Place, 14, 135-158.

Yüksel-Kaptanoglu, I., \& Ergöçmen, B. A. (2014). Early marriage: Trends in Turkey, 1978-2008. Journal of Family Issues, 35, 1707-1724. 